\title{
ANALISIS PENGEMBANGAN USAHA NENAS SAKINAH BERDASARKAN ASPEK KEUANGAN KONVENSIONAL DAN SYARIAH (HAMDI'S METHOD)
}

\author{
Hamdi Agustin, ${ }^{1}$ Novita Azmi, ${ }^{2}$ Armis ${ }^{3}$ \& Asril ${ }^{4}$ \\ 1,2,3\&4 Fakultas Ekonomi dan Bisnis, Universitas Islam Riau \\ Email :hamdiagustin@eco.uir.ac.id,azminovita2@gmail.com,armis@eco.uir.ac.iddan \\ asril@eco.uir.ac.id
}

\begin{abstract}
ABSTRAK
Penelitian ini dilakukan pada Usaha Keripik Nanas Sakinah yang terletak di Jl. Raya PekanbaruBangkinang, Km. 26,5 Kualu Nenas, Kecamatan Tambang, Kabupaten Kampar, Provinsi Riau. Tujuan penelitian ini adalah menganalisis pengembangan usaha Keripik Nanas Sakinah berdasarkan aspek-aspek keuangan. Analisis aspek keuangan berdasarkan konvensional terdiri dari Net Present Value (NPV), Payback Period (PP), Profitability Index (PI). Aspek keuangan berdasarkan syariah Islam dengan menggunakan Hamdi's Method terdiri dari Gold Value Method (GVM), Gold Index (GI) dan Investible Surplus Method (ISM). Hasil penelitian ini menunjukkan bahwa usaha Keripik Nanas Sakinah layak untuk dikembangkan berdasarkan hasil analisis aspek keuangan.
\end{abstract}

Kata Kunci : Kelayakan Usaha, Aspek Keuangan, Hamdi’s Method dan GVM.

\begin{abstract}
This research was conducted at Sakinah Pineapple Chips Business, which is located on Jl. Raya Pekanbaru-Bangkinang, Km. 26.5 Kualu Nenas, Tambang District, Kampar Regency, Riau Province. The purpose of this research is to analyze the development of the Sakinah Pineapple Chips business based on financial aspects. Conventional analysis of financial aspects consists of Net Present Value (NPV), Payback Period (PP), and Profitability Index (PI). Financial aspects based on Islamic sharia using Hamdi's Method consist of the Gold Value Method (GVM), Gold Index (GI) and Investible Surplus Method (ISM). The results of this study indicate that the Sakinah Pineapple Chips business is feasible to be developed based on the analysis of the financial aspects..
\end{abstract}

Keywords : Business Feasibility, Financial Aspects, Hamdi's Method and GVM. 


\section{PENDAHULUAN}

Kecamatan Tambang yang terkenal sebagai pusat penghasil nenas di Provinsi Riau. Tercatat perkebunan nenasnya mencapai 1.550 hektare (ha), sekitar 4,3 juta pohon, dengan total produksi mencapai 2.150 ton pertahun. Dari jumlah itu sekitar 1.050 ha berada di Desa Kualu Nenas dengan produksi 1.456 ton pertahun atau rata-rata 121 ton perbulan. Untuk mengatasi agar nenas tidak terbuang begitu saja, maka dari itu pemerintah mengadakan pelatihan kepada masyarakat Kecamatan Tambang, salah satunya Bapak Mardanis pemilik usaha keripik nenas Sakinah.

Keunggulan keripik nenas Usaha Sakinah pada di kemasannya yang berbeda dengan yang lain. Rasa dari keripik tersebut pun tidak asam atau kecut, kebanyakan keripik nenas dari toko lain, rasanya asam. Kemudian, keripik nenas ini tidak menggunakan pengawet dan dijamin halal. Dan ketahanannya sampai 3 bulan lamanya. Bahan yang digunakan hanya nenas, garam dan soda.

Usaha Sakinah menggunakan nenas dari kebun sendiri, sehingga ketika nenas dipanen bisa langsung diproduksi, agar kesegaran dari buah nenas terjaga. Untuk proses produksi, Usaha Sakinah sangat memperhatikan kebersihan dan kesehatan. Sampai pada proses packaging pun, Usaha Sakinah tetap menjaga higienis produknya.

Keripik nenas Usaha Sakinah ini sudah eksis di supermarket, seperti Mega Rasa, Viera, Cik Puan, Pasar Buah dan Toko Oleh-oleh. Sehingga Produksi keripik nenas Usaha Sakinah ini mencapai $300 \mathrm{~kg}$ dan setiap bulannya selalu bertambah kurang lebih $50 \mathrm{~kg}$. Berikut ini hasil produksi keripik nenas Usaha Sakinah Kecamatan Tambang, dengan data per bulan tahun 2018-2019 dapat dilihat pada tabel berikut.

\section{Tabel 1. Data Produksi Keripik Nenas Usaha Sakinah Tahun 2019}

(dalam per kilo gram)

\begin{tabular}{lccc}
\hline No. & Bulan & $\mathbf{2 0 1 8}$ & $\mathbf{2 0 1 9}$ \\
\hline 1 & Januari & 330 & 475 \\
\hline 2 & Februari & 380 & 440 \\
\hline 3 & Maret & 400 & 395 \\
\hline 4 & April & 445 & 418 \\
\hline 5 & Mei & 420 & 389 \\
\hline 6 & Juni & 390 & 445 \\
\hline 7 & Juli & 415 & 445 \\
\hline 8 & Agustus & 433 & 439 \\
\hline 9 & September & 410 & 455 \\
\hline 10 & Oktober & 415 & 510 \\
\hline 11 & Nopember & 425 & 536 \\
\hline 12 & Desember & 440 & 545 \\
\hline & Jumlah & $\mathbf{4 9 0 3}$ & $\mathbf{5 4 9 2}$ \\
\hline
\end{tabular}


Berdasarkan tabel diatas produksi keripik nenas Usaha Sakinah Kecamatan Tambang berfluktasi tiap bulannya selama 1 tahun. Hal ini disebabkan oleh permintaan pasar dan strategi pemasaran yang masih menggunakan metode sederhana.

Dalam peningkatan produksi dan permintaan ini sesuai dengan kondisi disaat perekonomian sedang normal. Seperti yang kita ketahui untuk pengembangan usaha disaat keadaan yang sebenarnya sekarang ini, sangat tidak memungkinkan. Karena adanya dampak Covid-19 yang membuat UMKM sulit berkembang dan mempertahankan usahanya. Dalam penelitian ini data sesuai dengan tingginya permintaan pasar dan peningkatan produksi sebelum adanya Covid-19.

Dengan meningkatnya produksi
Usaha Sakinah pertahun dan meningkatnya permintaan keripik nenas, sangat diperlukan peningkatan jumlah produksi untuk memenuhi permintaan pasar. Untuk meningkatkan jumlah produksi harus menambah kapasitas mesin dan gedung pengolahan. Oleh karena itu, pengembangan usaha menjadi pilihan tepat untuk dilakukan. Pengembangan usaha bertujuan untuk meningkatkan kapasitas produksi olahan yang dihasilkan dengan menambah unit produksi seperti gedung, mesin dan peralatan lain yang dapat digunakan untuk mendukung kegiatan produksi.

Adapun faktor-faktor yang harus dipertimbangkan dalam melakukan pengembangan, karena besarnya biaya pengembangan yang dikeluarkan. Dengan demikian, analisis pengembangan terhadap usaha pengolahan keripik nenas menjadi sangat penting dilakukan agar dapat diindentifikasi peluang untuk kedepan usaha nenas Sakinah ini. Maka sangat perlu dilakukan penelitian untuk menganalisis pengembangan usaha
Keripik Nanas Sakinah berdasarkan aspek-aspek keuangan. Analisis aspek keuangan berdasarkan konvensional terdiri dari Payback Period, Net Present Value dan Profitability Index.

Penelitian-penelitian menilaian
investasi menggunakan metode konvensional dilakukan oleh Thirawat, et al., (2013), Suzan dan Aboul-Nasr (2013), Jusuf et al., (2013), Victor dan Andreea (2014), Kusyanto (2014), Rizal et al., (2014), I Made P. (2015), kadek et al., (2017) dan Mahirun dan Akhmad (2018), sementara itu peneliti menilai investasi menggunakan metode syariah Islam dengan menggunakan Hamdi's Method telah dilakukan penelitian oleh Agustin (2017), Agustin dan Azwirman (2019). Analisis ini terdiri dari Gold Value Method (GVM), Gold Index (GI) dan Investible Surplus Method (ISM). Penelitian ini dapat bermanfaat bagi pemilik usaha nenas Sakinah sebagai bahan pertimbangan dalam pengambilan keputusan untuk mengembangkan usahanya.

\section{TINJAUAN PUSTAKA}

\section{a. Metode Payback Period (PP)}

Agustin (2017) Analisis payback period adalah waktu yang diperlukan untuk dapat menutup kembali pengeluaran investasi dengan menggunakan "proceeds" atau Net Cash Inflow. Inilah metode formal yang pertama kali digunakan untuk mengevaluasi proyek dalam capital budgeting. Cara termudah untuk menghitung payback period adalah dengan mengakulasikan arus kas berisi dari proyek hingga mencapai nilai positif, makin pendek periode pengambilan maka makin proyek yang dilakukan. Metode ini mempunyai kelemahan-kelemahan, kelemahan utama yaitu periode ini tidak memperhatikan konsep nilai waktu, uang dan tidak memperhatikan aliran kas masuk setelah payback. 


\section{b. Metode Net Present Value (NPV)}

Agustin (2017) salah satu pendekatan buat mengevaluasi usulan investasi dengan mendiskontokan pengeluaran kas serta setara kas dengan memberikan tingkatan bunga tertentu sepanjang masa usaha. Umar (2007) Net Present Value merupakan selisih antara present value dari investasi dengan nilai saat ini dari penerimaan- penerimaan kas bersih (aliran kas operasional ataupun aliran kas halte) pada waktu yang akan datang.

Kriteria penerimaaan proyek berdasarkan perhitungan NPV:

- Proyek diterima jika nilai NPV $>0$

○ Proyek ditolak jika nilai NPV $<0$

- Proyek ditolak jika nilai NPV $=0$

o Proyek ditolak jika nilai NPV ( - )

Keunggulan metode NPV dipandang sebagai pengukur profitabilitas suatu proyek yang baik karna metode ini memfokus pada kontribusi proyek kepada kemakmuran pemegang saham.

\section{c. Metode Internal Rate of Return (IRR)}

Agustin (2017) IRR ialah tingkatan bunga yang hendak menjadikan jumlah nilai saat ini dari proceeds yang diharap hendak diterima sama dengan jumlah nilai saat ini dari pengeluaran modal. Pada dasarnya buat menghitung IRR wajib dicari discount factor sehingga menciptakan NPV negatif mendekat ini lain nol apabila NPV awal bernilai positif. Umar (2017) Internal rate of return merupakan tata cara yang digunakan buat mencari tingkatan bunga yang membandingkan nilai saat ini dari arus kas yang diharapkan pada waktu yang akan datang, atau pun penerimaan kas, dengan pengeluaran investasi awal. Kasmir dan Jakfar (2009) IRR adalah alat buat mengukur tingkatan pengembalian hasil intern.
Kelemahan IRR ialah bila proyek mempunyai arus kas yang tidak wajar terdapat mungkin IRR tidak digunakan. Kas optimal serangkaian satu ataupun lebih arus kas keluar diiringi dengan serangkaian arus kas masuk. Arus kas tidak optimal apabila arus kas negatif (pengeluaran) timbul sepanjang bertahuntahun sehabis proyek berjalan.

\section{d. Metode Profitability Index (PI)}

Agustin (2017) Profitability Index (PI) ialah present value arus kas dibandingkan dengan nilai investasi. Jika hasil perhitungan PI lebih besar dari angka 1 maka investasi tersebut layak untuk dijalankan.

\section{e. Metode Gold Value (GVM)}

Agustin (2017) menyatakan bahwa Islam memakai prinsip, investasi harusnya tidak langsung memastikan untung terlebih dulu, tetapi dicoba dengan untuk hasil baik dalam kondisi untung ataupun rugi (profit and loss sharing). Prinsip ini lebih menjunjung keadilan, sebab hasil akhir suatu aktivitas bisnis yang sesungguhnya tidak tentu. Bila memastikan untung terlebih dulu, hingga kemungkinan dapat salah satu pihak bisa rugi. Sedangkan Islam menghendaki dikerjakannya hitungan untuk hasil secara adil dengan mengaitkan penyediaan dana dan pihak yang mengerjakan kegiatan usaha tersebut.

\section{f. Gold Indeks (GI)}

Gold Indeks (GI) merupakan rasio antara Present Value harga emas dibandingkan dengan Present Value harga emas dari pengeluaran aliran kas, Agustin (2017). Jika hasil perhitungan GI lebih dari angka satu maka usaha tersebut layak dan dapat dijalankan.

\section{g. Metode Investible Surplus (ISM)}

Agustin (2017) ISM yakni seberapa besar surplus investasi usaha yang dicoba sepanjang waktu berjalan, 
dengan menghitung beberapa tahun dalammendapatkan surplus investasi yang hendak diraih industri dengan kenaikankeuangan. Metode ISM di ciptakan oleh Khan (1992). Tujuan penggunaan metode ISM ini adalah membuat alternatif untuk mengganti metode NPV yang ada unsur bunga. Metode ini digunakan untuk menghitung nilai waktu uang suatu investasi dalam prinsip Islam. Perhitungan dan metode Investible Surplus Method menggunakan formula yang sederhana dan rasional yang disesuaikan dengan nilai waktu uang.

Penelitian studi kelayakan bisnis mengunakan Hamdi's Method dilakukan Agustin (2017). Judul penelitian tersebut adalah analisis keuangan kelayakan bisnis syariah Hamdi's Method (Studi Kasus Usaha Swalayan Syariah di Pekanbaru). Hasil penelitian menujukkan bahawa hasil perhitungan aspek keuangan menunjukkan bahwa analisis studi kelayakan bisnis syariah dengan menggunakan Hamdi's method menunjukkan analisis perhitungan dengan metode syariah berupa Hamdi's Method yang terdiri perhitungan Gold Value Method (GVM), Metode Gold Indeks (GI) dan Analisis Investible Surplus Method dapat digunakan dalam menilai kelayakan investasi.

Penelitian dilakukan oleh Agustin dan Azwirman (2019). Penelitian ini berjudul The Analysis Feasibility Study on the Financial Aspects of Islamic Perspective. Tujuan dari penelitian ini adalah menghitung kelayakan investasi pada aspek keuangan dengan menggunakan perspektif Islam yaitu Metode Hamdi'. Metode Hamdi menggunakan metode perhitungan nilai emas (GVM) dan indeks emas (GI) yang merupakan pengganti perhitungan dalam konsep konvensional yaitu nilai sekarang bersih (NPV) dan indeks profitabilitas (PI). Metode GVM dan GI merupakan metode baru untuk menghitung aspek keuangan dalam menentukan kelayakan investasi dalam perspektif Islam. Hasil perhitungan menunjukkan bahwa bisnis kursus bahasa Inggris layak dengan menggunakan Metode Hamdi. Hasilnya sama dengan menggunakan perhitungan NPV dan PI. Dengan demikian penghitungan kelayakan investasi pada aspek keuangan dengan menggunakan perspektif Islam yaitu Metode Hamdi dapat digunakan sebagai metode baru dalam bidang akademik.

\section{METODE PENELITIAN}

Penelitian ini dilaksanakan ditempat Usaha Sakinah yang berada di Jl. Raya Pekanbaru-Bangkinang, Km. 26,5 Kualu Nenas, Kecamatan Tambang, Kabupaten Kampar, Provinsi Riau. Jenis dan sumber data pada penelitian ini ialah data primer dimana peneliti langsung menemui pemilik usaha. Teknik pengumpulan data dengan cara wawancara dan observasi pada usaha nenas Sakinah. Analisis data dalam penelitian ini adalah analisis kuantitatif, dengan menggunakan rumus untuk menghitung kelayakan finansial usaha nenas Sakinah sesuai dengan kriteria kelayakan usaha dalam perspektif konvensional yaitu :

\section{Payback Period (PP)}

$\mathrm{PP}=\mathrm{L}_{0}-\mathrm{C} 1_{1}-\mathrm{C} 2_{2} \ldots \ldots \ldots \ldots \ldots \ldots \ldots \ldots \ldots 1_{n}$

Keterangan :

$\mathrm{PP}=$ Payback Period

$\mathrm{C} 1=$ Cash inflow Pertahun

$\mathrm{L}_{0}=$ Dana Investasi Awal

\section{Net Present Value (NPV)}

$$
N P V=\sum_{t=1}^{n}\left(B_{t}-C_{t}\right) /(1+i)^{t}
$$

Keterangan :

$\mathrm{B}_{\mathrm{t}} \quad=$ Cash inflow pada tahun $\mathrm{t}$

$\mathrm{C}_{\mathrm{t}}=$ Modal yang dikeluarkan pada tahun $\mathrm{t}$ 
$\mathrm{n}=$ Umur ekonomis investasi

$\mathrm{i} \quad=$ Tingkat suku bunga kredit di bank

\section{Profitability Index (PI).}

$\sum$ PV Kas Bersih

$$
\mathrm{PI}=\frac{\sum \mathrm{PV}}{\sum \mathrm{PV} \text { Investasi }} \times 100 \%
$$

Kriteria penerimaan proyek dengan menggunakan metode PI :

- Proyek diterima jika nilai PI > 1

- Proyek diterima jika nilai PI = 1

- Proyek ditolak jika nilai PI $<1$

\section{Internal Rate of Return (IRR)}

$$
\text { IRR }=\mathrm{i}_{\mathrm{i}}+\frac{\mathrm{NPV} 1}{\mathrm{NPV} 1-\mathrm{X}\left(\mathrm{i}_{\mathrm{i}}-\mathrm{i}_{2}\right)}
$$

Keterangan :

$$
\begin{array}{ll}
\mathrm{i}_{\mathrm{i}} & =\text { Bunga } 1 \\
\mathrm{i}_{2} & =\text { Bunga } 2 \\
\mathrm{NPV}_{1} & =\text { Hasil NPV pada bunga } 1 \\
\mathrm{NPV}_{2} & =\text { Hasil NPV pada bunga } 2
\end{array}
$$

Kriteria penerimaan proyek dengan menggunakan metode IRR adalah:

- Proyek diterima jika IRR > bunga pinjaman

- Proyek diterima jika IRR = bunga pinjaman

- Proyek ditolak jika IRR < bunga pinjaman

Sedangkan rumus perhitungan metode penilaian kelayakan usaha dalam perspektif Islam dengan menggunakan Hamdi's model terdiri dari :

\section{Gold Value Method (GVM)}

Rumus metode Gold Value Method (GVM) ditulis sebagai berikut dibawah ini :

$\mathrm{GVM}_{\mathrm{n}}=\sum_{\mathrm{t}} \mathrm{n}^{\mathrm{n}}=\left(\mathrm{LB}_{\mathrm{t}} \mathrm{x} \mathrm{N}_{\mathrm{t}}\right):\left(\mathrm{HE}_{\mathrm{t}}\right)-\mathrm{INV}$

$\mathrm{IS}_{\mathrm{n}} \quad=$ Surplus investasi selama $\mathrm{n}$ tahun

$\mathrm{LB}_{\mathrm{t}} \quad=$ Laba bersih (aliran kas masuk)

$\mathrm{N}_{\mathrm{t}} \quad=$ Nisbah bagi hasil

$\mathrm{HE}_{\mathrm{t}} \quad=$ Laba bersih (aliran kas masuk)

INV = Investasi awal

$\mathrm{N}=$ Umur proyek

$\mathrm{t}=$ Suatu periode waktu

\section{Metode Gold Index (GI)}

$$
\mathrm{GI}=\frac{\text { Total Pendapatan Emas (gram) }}{\text { Jumlah Investasi Awal (gram) }}
$$

\section{Investible Surplus Method (ISM)}

$$
\sum_{t_{1}=0}^{N} I S_{n}(c t)\left(b-t_{1)} X 100 \%\right.
$$

Keterangan :

$\mathrm{IS}_{\mathrm{n}} \quad=$ Surplus investasi setelah ke-n tahun

$\mathrm{B}_{\mathrm{t}} \quad=$ Keuntungan yang diperoleh

$\mathrm{C}_{\mathrm{t}} \quad$ = Biaya yang dibutuhkan

$\mathrm{N}=$ Usia usaha

$\mathrm{t}=$ Periode waktu

\section{HASIL DAN PEMBAHASAN}

Analisis Arus Kas (Cash Flow)

Adapun rincian arus kas usaha Sakinah terangkum pada tabel berikut ini: 
Tabel 2. Arus Kas (Cash Flow) Usaha Keripik Nanas Sakinah

\begin{tabular}{|c|c|c|c|c|c|}
\hline Keterangan & Tahun ke-1 & Tahun ke-2 & Tahun ke-3 & Tahun ke-4 & Tahun ke-5 \\
\hline \multicolumn{6}{|l|}{ Penerimaan } \\
\hline Penjualan Keripik Nanas & 337.500 .000 & 405.000 .000 & 522.000 .000 & 585.000 .000 & 651.000 .000 \\
\hline Total Penerimaan & 337.500 .000 & 405.000 .000 & 522.000 .000 & 585.000 .000 & 651.000 .000 \\
\hline \multicolumn{6}{|l|}{$\begin{array}{l}\text { HPP (Harga Pokok } \\
\text { Penjualan) }\end{array}$} \\
\hline Bahan Baku & 100.752 .000 & 108.783 .360 & 117.534 .720 & 127.006 .080 & 137.139 .840 \\
\hline Gas & 7.200 .000 & 8.580 .000 & 10.080 .000 & 11.700 .000 & 13.440 .000 \\
\hline Listrik & 6.000 .000 & 7.200 .000 & 8.400 .000 & 9.600 .000 & 10.800 .000 \\
\hline Bahan Bakar & 9.600 .000 & 10.200 .000 & 10.800 .000 & 11.400 .000 & 12.000 .000 \\
\hline Gaji Karyawan & 72.000 .000 & 72.000 .000 & 72.000 .000 & 81.600 .000 & 81.600 .000 \\
\hline Perawatan Kendaraan & 8.760 .000 & 10.500 .000 & 11.080 .000 & 12.400 .000 & 13.250 .000 \\
\hline Total Harga Pokok Penjualan & 204.312.000 & 217.263 .360 & 229.894 .720 & 253.706.080 & 268.229.840 \\
\hline Laba Kotor & 133.188.000 & 187.736 .640 & 292.105 .280 & 331.293.920 & 382.770 .160 \\
\hline \multicolumn{6}{|l|}{ Biaya-Biaya } \\
\hline Administrasi Lain-lain & 1.000 .000 & 1.500 .000 & 2.000 .000 & 2.500 .000 & 3.000 .000 \\
\hline Penyusutan & 43.943 .536 & 43.943 .536 & 43.943 .536 & 43.943 .536 & 43.943 .536 \\
\hline Total Biaya-Biaya & 44.943.536 & 45.443.536 & 45.943.536 & 46.443 .536 & 46.943.536 \\
\hline Laba Sebelum Pajak & 88.244.464 & 142.293 .104 & 246.161 .744 & 284.850 .384 & 335.826.624 \\
\hline Pajak Penghasilan $15 \%$ & 13.236 .670 & 21.343 .966 & 36.924 .262 & 42.727 .558 & 50.373 .994 \\
\hline Laba Bersih & 75.007.794 & 120.949 .138 & 209.237.482 & 242.122 .826 & 285.452 .630 \\
\hline Cash Flow & 118.951.330 & 164.892.674 & 253.181.018 & 286.066 .362 & 329.396.166 \\
\hline
\end{tabular}

Sumber : Data Peneliti (2021)

1. Payback Period (PP)

Untuk perhitungan Payback Period (PP) dapat dilihat di bawah ini :

$\begin{array}{lll}\text { Investasi } & : & 358.169 .000 \\ \text { Arus Kas I } & : & \frac{118.951 .330}{239.217 .670}- \\ \text { Arus Kas II } & : & 239.217 .670 \\ & : & \frac{164.892 .674}{74.324 .996}- \\ & & \frac{74.324 .996}{253.181 .018} \\ \text { Arus Kas III } & : & =0,294 \times 12=3,53 \\ & =0,53 \times 30=15,9\end{array}$

Hasil perhitungan Payback Period (PP) usaha keripik nanas Sakinah adalah 2 tahun 3 bulan dan 15 hari.

\section{Net Present Value (NPV)}

Dalam metode perhitungan NPV terlebih dahulu harus diketahui present value dan keuntungan setiap tahun perusahaan. Kemudian pendapatan tersebut dikurangi dengan biaya-biaya beban setiap tahunnya. Dalam metode ini, dapat dilihat selisih antara nilai saat ini dan aliran kas bersih dan nilai saat ini dari total keseluruhan investasi awal perusahaan. Dapat dilihat di tabel berikut ini : 
Tabel 3. Perhitungan Net Present Value (NPV) Usaha Keripik Nanas Sakinah

\begin{tabular}{|c|c|c|c|c|}
\hline Tahun Ke & Arus Kas (Rp) & Df $6,48 \%$ & & PV (Rp) \\
\hline 1. & 118.951 .330 & 0,939 & $\mathrm{Rp}$ & 111.695 .299 \\
\hline 2. & 164.892 .674 & 0,882 & $\mathrm{Rp}$ & 145.435 .338 \\
\hline 3. & 253.181 .018 & 0,828 & $\mathrm{Rp}$ & 209.633 .883 \\
\hline 4. & 286.066 .362 & 0,778 & $\mathrm{Rp}$ & 222.559 .630 \\
\hline 5. & 329.396 .166 & 0,731 & $\mathrm{Rp}$ & 240.788 .597 \\
\hline \multicolumn{3}{|c|}{ Arus Kas Bersih } & $\mathbf{R p}$ & 930.112.747 \\
\hline \multicolumn{3}{|c|}{ Investasi } & $\mathbf{R p}$ & 358.169 .000 \\
\hline \multicolumn{3}{|c|}{ NPV } & $\mathbf{R p}$ & 571.943 .747 \\
\hline
\end{tabular}

Nilai Net Present Value (NPV) positif (+) yaitu Rp. 571.943.747,-, jadi usaha keripik nanas Sakinah layak untuk dilakukan.

\section{Profitability Index (PI)}

Hasil perhitungan PI dapat dilihat sebagai berikut :

Profitability Index $(\mathrm{PI}) \quad=\mathrm{PV}$ Arus Kas

Investasi

$$
\begin{aligned}
& =\frac{930 \cdot 112.747}{358 \cdot 169 \cdot 000} \\
& =2,596
\end{aligned}
$$

Nilai Profitability Index (PI) diatas 1 (PI>1) yaitu 2,59, maka investasi usaha keripik nenas Sakinah layak untuk jalankan.

4. Internal Rate of Return (IRR)

Tabel 4. Perhitungan Internal Rate of Return (IRR) Usaha Keripik Nanas Sakinah

\begin{tabular}{cccccc}
\hline Tahun & Arus Kas & $\begin{array}{c}\text { Df } \\
(\mathbf{6 , 4 8 \%})\end{array}$ & $\begin{array}{c}\text { Present Value } \\
(\mathbf{P V})\end{array}$ & Df (57\%) & $\begin{array}{c}\text { Present Value } \\
(\mathbf{P V})\end{array}$ \\
\hline 2020 & 118.951 .330 & 0,939 & 81.957 .466 & 0.636 & 75.653 .046 \\
\hline 2021 & 164.892 .674 & 0,882 & 78.324 .020 & 0.405 & 78.324 .020 \\
\hline 2022 & 253.181 .018 & 0,828 & 83.043 .374 & 0.258 & 83.043 .374 \\
\hline 2023 & 286.066 .362 & 0,778 & 64.650 .998 & 0.164 & 64.650 .998 \\
\hline 2024 & 329.396 .166 & 0,731 & 51.385 .802 & 0.104 & 51.385 .802 \\
\hline \multicolumn{5}{c}{ Jumlah PV Arus Kas } & 930.112 .747 \\
\hline
\end{tabular}

Penjelasan :

Diketahui : $\mathrm{PI}=6,48 \% \quad \mathrm{CI}=571.943 .747$

$$
\mathrm{P} 2=57 \% \quad \mathrm{C} 2=(88.155 .134)
$$

$\mathrm{IRR}=\mathrm{PI}-\mathrm{CI}+\left\{\frac{P 2-P 1}{C 2-C 1}\right\} \times 1 \%$

$$
\begin{aligned}
& =6,48 \%-571.943 .7472+\left\{\frac{57 \%-6,48 \%}{88.155 .134-571.943 .747}\right\} \times 1 \% \\
& =6,48 \%+\left\{\frac{50,52 \% \times 571.943 .747}{-660.098 .881}\right\} \times 1 \% \\
& =6,48 \%+0,4377=50,25 \%
\end{aligned}
$$


Dari perhitungan Internal Rate of Return (IRR) pada Usaha Keripik Nanas Sakinah menunjukkan bahwa modal yang diinvestasikan sebesar Rp. 358.169.000,apabila dibandingkan dengan bunga atau biaya atau biaya modal sebesar $6,48 \%$ maka investasi layak diterima karena hasil perhitungan IRR diatas biaya modal yang sangat tinggi yaitu sebesar 50,25\% .

\section{Investible Surplus Method (ISM)}

Hasil perhitungan investible surplus yang ada di keripik nanas usaha sakinah pada tabel di bawah ini :

Tabel 5. Perhitungan Investible Surplus Method (ISM) Usaha Keripik Nanas Sakinah

\begin{tabular}{|c|c|c|c|c|c|c|}
\hline Period & Bt & $\mathbf{C t}$ & $(\mathbf{B t}-\mathrm{Ct})=\mathrm{IS}$ & $\begin{array}{l}\text { n- } \\
\text { t }\end{array}$ & IS $x(n-t)$ & Isn \\
\hline 0 & 0 & $\begin{array}{r}358.169 .00 \\
0\end{array}$ & -358.169 .000 & & 0 & 0 \\
\hline 1 & $\begin{array}{r}118.951 .33 \\
0\end{array}$ & 0 & -239.217 .670 & & 0 & 0 \\
\hline 2 & $\begin{array}{r}164.892 .67 \\
4\end{array}$ & 0 & -74.324 .996 & & 0 & 0 \\
\hline 3 & $\begin{array}{r}253.181 .01 \\
8\end{array}$ & 0 & 178.856 .022 & 2 & $178.856 .022 \times 2$ & 357.712 .044 \\
\hline 4 & $\begin{array}{r}286.066 .36 \\
2\end{array}$ & 0 & 464.922 .384 & 1 & $464.922 .384 \times 1$ & 464.922 .384 \\
\hline 5 & $\begin{array}{r}329.396 .16 \\
6\end{array}$ & 0 & 794.318 .550 & 0 & $794.318 .550 \times 0$ & 0 \\
\hline
\end{tabular}

Sumber : Data Olahan (2021)

$\begin{array}{lllll}\text { Isn } & =822.634 .428 & \text { ISR } & =\frac{822.634 .428}{1.790 .845 .000} & \\ & & & \\ \mathrm{Ct} & =358.169 .000 & & 45,94 \% & \end{array}$

$\mathrm{n}-\mathrm{t} 1 \quad=(5-0)=5$

$(\mathrm{Ct})(\mathrm{n}-\mathrm{t} 1)=358.169 .000 \times 5$

6. Gold Value Method (GVM)

Tabel 6. Perhitungan Gold Value Method (GVM) Usaha Keripik Nanas Sakinah

\begin{tabular}{|c|c|c|c|c|c|}
\hline Tahun & $\begin{array}{l}\text { Laba Bersih } \\
\quad(\mathbf{R p})\end{array}$ & $\begin{array}{c}\text { Nisbah Bagi } \\
\text { Hasil }\end{array}$ & $\begin{array}{c}\text { Pendapatan } \\
\text { (Rp) }\end{array}$ & $\begin{array}{c}\text { Harga Emas } \\
\text { (Per Gram) }\end{array}$ & $\begin{array}{c}\text { Nilai } \\
\text { Pendapatan } \\
\text { Setelah } \\
\text { dijadikan } \\
\text { Gram Emas }\end{array}$ \\
\hline 1 & 75.007 .794 & 0,52 & 39.004 .053 & 951.261 & 41,00 \\
\hline 2 & 120.949 .138 & 0,52 & 62.893 .552 & 980.594 & 64,14 \\
\hline 3 & 209.237.482 & 0,52 & 108.803 .491 & 1.011 .393 & 107,58 \\
\hline 4 & 242.122 .826 & 0,52 & 125.903 .870 & 1.043 .732 & 120,63 \\
\hline 5 & 285.452 .630 & 0,52 & 148.435 .368 & 1.077 .688 & 137,74 \\
\hline \multicolumn{3}{|c|}{ Total Pendapatan Emas (Gram) } & & & 471,08 \\
\hline \multicolumn{3}{|c|}{ Jumlah Investasi Awal (Gram) } & 358.169.000 & 951.261 & $\mathbf{3 7 6 , 5 2}$ \\
\hline \multicolumn{3}{|c|}{ Nilai Pendapatan Emas (Gram) } & & & 94,56 \\
\hline
\end{tabular}


Berdasarkan Profit Sharing dengan nisbah 52:48, jumlah pendapatan emas adalah 94 gram. Artinya, jika usaha keripik nanas Sakinah ini didirikan maka pengelola dana dapat keuntungan sebesar 94 gram, maka ini layak dan dapat dijalankan.

\section{Gold Index (GI)}

Adapun rumus metode GI adalah sebagai berikut :

$\mathrm{GI}=\frac{\text { Total Pendapatan Emas (Gram) }}{\text { Jumlah Investasi Aawal (Gram) }}$
GI

$$
=\underline{471,08}=1,25
$$

\section{6,52}

Dari hasil perhitungan gold index (GI) lebih dari 1, maka usaha keripik nanas Sakinah layak untuk dijalankan.

Berdasarkan hasil perhitungan analisis kelayakan investasi yang dilakukan pada usaha keripik nanas Sakinah diatas, maka dapat dilakukan rekapitulasi hasil analisis metode kelayakan usaha sebagai berikut:

Tabel 7. Perhitungan Model Kelayakan Usaha

\begin{tabular}{llll}
\hline No. & Metode Kelayakan & Hasil & $\begin{array}{c}\text { Keputusan } \\
\text { Berdasarkan Metode } \\
\text { Kelayakan }\end{array}$ \\
\hline 1. & Payback Period (PP) & (2 tahun 3 bulan 15 hari) & Layak \\
\hline 2. & Net Present Value (NPV) & Rp. 571.943.747. & Layak \\
\hline 3. & Profitability Index (PI) & 2,59 & Layak \\
\hline 4 & Internal Rate of Return (IRR) & $50,25 \%$ & Layak \\
\hline 5. & $\begin{array}{l}\text { Investible Surplus Method } \\
\text { (ISM) }\end{array}$ & $45,94 \%$ & Layak \\
\hline 6. & Gold Value Method (GVM) & 94 Gram Emas & Layak \\
\hline 7. & Gold Index (GI) & 1,25 & Layak \\
\hline
\end{tabular}

\section{Sumber : Data Olahan (2021)}

\section{KESIMPULAN}

Berdasarkan perhitungan menggunakan metode Payback Period (PP) maka diperoleh masa Payback Period selama 2 tahun 3 bulan 15 hari. Dengan menggunakan metode Net Present Value diperoleh nilai (NPV) positif yaitu Rp. 571.943.747, hal ini berarti usaha yang dijalankan layak untuk dikembangkan. Berdasarkan hasil perhitungan dari metode Profitability Index (PI) menunjukkan bahwa Usaha Keripik Nanas Sakinah layak karena Profitability Index (PI) lebih dari 1 (satu), yaitu sebesar 2,59, maka investasi ini layak untuk diterima. Menggunakan kedua tingkat pengembalian maka IRR sebesar $50,25 \%$ nilai yang melebihi nilai modal yaitu sebesar 6,48\%. Artinya, modal yang diinvestasikan sebesar Rp. 358.169.000,- apabila dibandingkan dengan biaya modal atau bunga yang disyaratkan sebesar $6,48 \%$ diperoleh IRR lebih tinggi yaitu $6,87 \%$, maka investasi ini layak untuk dikembangkan. Perhitungan dengan menggunakan metode Investible Surplus Method (ISM) menunjukkan bahwa nilai surplus investasi selama 5 tahun adalah sebesar 45,94\%. Perhitungan menggunakan metode Gold Value Method (GVM) diperoleh nilai sebesar 94,56 Gram Emas 
selama 5 tahun. Perhitungan dengan menggunakan Gold Index (GI) diperoleh hasil sebesar 1,25 yang mana lebih besar dari 1 (satu). Setelah dihitung menggunakan analisis finansial dengan menggunakan analisis keuangan konvensional yaitu Payback Period (PP), Net Present Value (NPV), Profitability Index (PI), Internal Rate of Return (IRR) menunjukkan hasil keputusan layak. Analisis keuangan syariah (Hamdi's model) terdiri dari Investible Surplus Method (ISM), Gold Value Method (GVM) dan Gold Index (GI) juga menunjukkan hasil layak. Dengan demikian dapat diatarik suatu kesimpulan bahwa usaha keripik nanas Sakinah dapat dikembangkan.

\section{DAFTAR PUSTAKA}

Agustin, Hamdi dan Azwirman. 2019. The Analysis Feasibility Study on the Financial Aspects of Islamic Perspective. Advances in Economics, Business and Management Research, 132, p. 6973.

Agustin, Hamdi. 2017. Analisis Keuangan Kelayakan Bisnis Syariah Hamdi's Model (Studi Kasus Usaha Swalayan Syariah di Pekanbaru). Jurnal Manajemen Bisnis Indonesia, 4(3), p. 295-305.

Agustin, Hamdi. 2017. Studi Kelayakan Bisnis Syariah. PT. Rajawali Press. Jakarta.

I Made P. 2015. Analisis Kelayakan Investasi Pasar Tradisional Desa Padangsambia di Denpasar Bali. Jurnal Teknik Sipil Untag Surabaya, 8(1), p. 79-94.

Jusuf, O. Panekenan, J.C. Loing, B. Rorimpandey dan P.O.V Waleleng. 2013. Analisis Keuntungan Usaha Beternak Puyuh di Kecamatan Sonder Kabupaten Minahasa. Jurnal Zootek, 32(5), p. 1-10.
Kadek S. I. G. B., Wiksuana, dan Luh G.R. 2017. Studi Kelayakan Pembangunan Pusat Pembelanjaan Cokroaminoto. E-Jurnal Ekonomi dan Bisnis Universitas Udayana, 6(2), p. 789-818.

Kasmir \& Jakfar. 2009. Studi Kelayakan Bisnis. Kencana. Jakarta.

Khan, M. Akram. 1992. Time Value of Money, dalam An Introduction to Islamic Finance Ch. 7 (Abod, Agil, dan Ghazali). Quill Publishers. Kuala Lumpur.

Kusyanto. 2014. Analisis Kelayakan Ekonomi dan Financial Pendirian Perusahaan Daerah Jasa Pelaksana Kontruksi di Kabupaten Pemalang. Jurnal Eko-Regional, 9(2), p. 63-74.

Mahirun dan Akhmad, S. 2018. Studi Kelayakan Penyertaan Modal Kabupaten Pekalongan Kepada Pihak Ketiga. Jurnal PENA, 32(1), p. 1-10.

Rizal, Fathurohman., Bakar, Abu., dan Fitria, Lisye. 2014. Analisis Kelayakan Usaha Peternakan Burung Puyuh di Daerah Pasir Kawung Cileunyi Kabupaten Bandung. Jurnal Online Institut Teknologi Nasional, 03(02), p. 1-12.

Suzan, Abdelmajeed A., dan M. H. Aboul-Nasr. 2013. Financial Feasibility Study of Bananas Tissue Culture Commercial Production in Egypt. Journal of Finance, Accounting and Management, 4 (2), p. 87-96.

Thirawat, Chantuk., Teera Kulsawat dan Klangburam, Nawalak. 2013. Feasibility Analysis of Investment Project on Housing Development in Thailand with Valuation Technique based on Economy Factor. The Asian Conference on Society, Education, and Technology Official Conference Proceedings, Japan 
2021, Jurnal Tabarru' : Islamic Banking and Finance 4 (1) : 219 - 230

Umar, Husein. 2007. Studi Kelayakan Bisnis. Edisi Ketiga. Cetakan Kesembilan. PT Gramedia Pustaka Utama. Jakarta.

Victor P. dan Andreea C. 2014. Monte Carlo Method in Risk Analysis for Investment Projects. Procedia Economics and Finance, 15, p. 393400 . 